\title{
Examining the Dimensions of Corporate Entrepreneurship Construct: A Validation Study in the Pakistani Banking Context
}

\author{
Waheed Ali Umrani ${ }^{1}$ \\ Rosli Mahmood² \\ ${ }^{1} \mathrm{PhD}$ Scholar University Utara Malaysia; Lecturer Sukkur Institute of Business Administration \\ Sindh, Pakistan; waheed.ali@iba-suk.edu.pk \\ ${ }^{2}$ College of Business, University Utara Malaysia; rosli@uum.edu.my
}

Doi:10.5901/mjss.2015.v6n6p278

\section{Abstract}

Corporate Entrepreneurship is globally advancing phenomena. Organizations in the search of excellence, increase in their financial and non-financial gains are adopting corporate entrepreneurship for a better tomorrow. Prominent scholars played a significant role in the development, understanding and advancement of corporate entrepreneurship. In this respect, particularly for measuring the state of corporate entrepreneurial activities inside a firm, the researchers developed tools to measure and assess it. In pursuing that objective the Corporate Entrepreneurship Assessment Instrument (CEAl) was developed. As this instrument was mainly developed and tested in the United States and Canada therefore, in this study the psychometric properties of Corporate Entrepreneurship Assessment Instrument construct are assessed in the Pakistan's context. Two hundred and sixty five bank branch managers from big five banks of Pakistan were surveyed. We analysed the data using Smart PLS 3.0 software due to its methodological usefulness. The findings demonstrated that the scale has adequate level of internal consistency reliability, convergent validity and discriminant validity for each CEAI dimension. Based on above findings, it is suggested that CEAl construct can be effective in measuring the corporate entrepreneurship in the banking sector of Pakistan. Therefore, the potential researchers are suggested to employ this tool in measuring corporate entrepreneurship in the developing countries and in Pakistan specially.

Keywords: Corporate Entrepreneurship Assessment Instrument, CEAl, Banks, Pakistan, psychometric properties

\section{Introduction}

Scholars suggest firms to nurture entrepreneurship into their existing body; however, literature has exclusively elaborated the term internal orientation of an organization towards entrepreneurship. These elaborations have created more confusion in the literature for the practicing managers in understanding this phenomenon. Among many, a few prominent scholars contributed to the body of literature, simplifying this concept for perspective researchers and practitioners; from naming it as entrepreneurial mindset, goal-orientation and optimism, new organization creation and renewal, corporate venturing, intrapreneurship, entrepreneurial orientation (Chittipeddi \& Wallett, 1991; McGrath \& MacMillan, 2000; Kuratko et al., 2001; Lumpkin \& Dess, 2005; and Ireland et al., 2006) they also called it corporate entrepreneurship. Defining it as the study of an organization's internal environment. Besides this, some of these researchers have also highlighted that the cultivation of corporate entrepreneurship is almost impossible without the involvement of middle managers. These middle managers could play a significant role for promoting corporate entrepreneurship (Floyd \& Woolridge, 1992; Ginsberg \& Hey, 1994; and Pearce et al., 1997).

A healthy number of studies have also underlined numerous internal factors affecting organization's effectiveness (performance) from the incentive and control systems perspective of a company (Sathe, 1985), to organizational structure (Covin \& Slevin, 1991; Hisrich \& Peters, 1986; Brazeal, 1983; and Kanter, 1985) and managerial support (Stevenson \& Jarillo, 1990). In such pursuit (Hornsby et al., 1992) developed CEAl scale consisting of five dimensions. Hornsby et al., (2002) assessed the scale with two individual samples of 231 and 530 middle level managers respectively. The studies were conducted in the United States and Canada and reported its usefulness. Hence present study argues that there is a need to validate CEAI in the developing countries.

In the following sections we explain the literature review, method used in the present study followed by results in section 4. Conclusions are drawn on the basis of the findings of the present study in the last section. 


\section{Review of Literature}

A large array of scientific literature is available that explains corporate entrepreneurship. It says that among the most common research areas in the domain of Entrepreneurship is corporate entrepreneurship (Hagen, Emmanuel and Alshare, 2005). The investigation of corporate entrepreneurship has been made in a wider perspective. The corporate entrepreneurship has been complimented with organizational strategy. This strategy level contribution of corporate entrepreneurship is due to its activities such as innovation, ability to take risk and being proactive (Collin and Smith, 2003; Rauch, Wilklund, Lumpkin and Frese, 2009). While studies have also emphasized on differentiating corporate entrepreneurship antecedents, its elements and outcomes or consequences. In doing so, the work of Ireland, Covin, and Kuratko, (2009) emphasized on external environmental conditions; organization's structure and its strategic vision. Similarly, the work of Collin and Smith (2003) have discussed the determinants of corporate entrepreneurship; explaining how and what bearing corporate entrepreneurship leaves on organizational performance.

More recently, Morris et al., (2011) described corporate entrepreneurship as "entrepreneurial behavior inside established mid-size and large organizations". This view of defining of corporate entrepreneurship is also supported by (Heavey \& Simsek, 2013); who stated corporate entrepreneurship as an effective mean for small and medium enterprises (SMEs) for their renewal. According to Bierwerth, Schwens, Isidor, \& Kabst, (2015) the corporate entrepreneurship's role in complimenting business performance is very important. Business can practice corporate entrepreneurship to gain strategic as well as financial benefits (Phan et al., 2009). The motives of a business behind the implementation of corporate entrepreneurship are seen differently in the literature. To one end it is practiced to gain objective performance that includes profitability, return on sales (ROS) and return on assets (ROA); this notion of how corporate entrepreneurship benefits financially to a firm is evident in the work of Zahra et al., 2000 and Zahra \& Covin, 1995) beside many other prominent scholars. The other motive for business to practice corporate entrepreneurship is due to its surprising impact on subjective performance of a business. This includes perceived non-financial performance such as customer satisfaction (e.g., Ag ca et al. 2012); perceived financial performance such as perception regarding profitability of a business in comparison with its major competitors, the evidence for this notion of corporate entrepreneurship research can be found in the work of Simsek and Heavey, (2011) beside many others. Corporate entrepreneurship compliments business performance (financial, non-financial or a combination of the two) is also evident in the recent work (Frese, Rousseau, \& Wiklund, (2014); García-Morales, Bolívar-Ramos, \& Martín-Rojas, (2014); Heavey, \& Simsek, (2013); Zahra, (2012); Ag ca, Topal, \& Kaya, (2012); Morris, , Kuratko, \& Covin, (2011); Simsek, \& Heavey, (2011); Espinosa, \& Suanes, (2011); Lisboa, Skarmeas, \& Lages, (2011); Jones, Coviello, \& Tang, (2011); Al-Swidi, \& Mahmood, 2011); Zahra, (2010); Benitez-Amado, Llorens-Montes, \& Perez-Arostegui, (2010). The above literature also witnesses that corporate entrepreneurial practices within an organization have been seen differently. Particularly in terms of measuring corporate entrepreneurship there have been a great debate in the past literature (Collin and Smith, 2003; Rauch, Wilklund, Lumpkin and Frese, 2009).

After a comprehensive review of the literature, Hornsby et al., (1992) developed CEAI scale. This scale addressed measuring the corporate entrepreneurship within an organization on five basis (dimensions). The same study was reassessed by Hornsby et al., (2002) with two different samples of middle level managers in the United States and the Canada. These studies gave rise to CEAI scale; but unfortunately, these and other studies, where CEAI has been used, have been conducted more in the developed countries. As the concern relating to cultural differences in less developed or developing countries still remains there. Hence there is potential need to address this issues of how do psychometric properties of CEAI scale score in the developing economies. To address this question, present study aims at re-validating the CEAI scale in the banking industry in Pakistan. This study will potentially fill the knowledge gap in the existing body of literature by examining the psychometric properties of CEAI construct in Pakistani context. In doing so, the present study seeks to address the following research question: What are the psychometric properties of CEAI and its factor structure in Pakistani context?

\section{Methods}

\subsection{Sampling and Population}

Using proportionate stratified random sampling, a total of 650 questionnaires were distributed, posing to the bank branch managers of the big five banks in Pakistan. The data was collected using the list from Pakistan Banks Association, (2014); drawing upon (Krejcie \& Morgans, 1970), 265 responses were received thus making the response rate up to 40\%. 


\subsection{Demographic Profile}

Two hundred and sixty five participants were surveyed from big five banks of Pakistan. The majority of the population comprised of male $85.7 \%$. The majority of participants turned out to be operations managers with $62.3 \%$ and the second highest population was of branch managers with $35.1 \%$. In terms of qualifications the major (67.2\%) had post graduate degree, followed by undergraduate degree (27.9\%) amongst others. Out of these participants $46.4 \%$ had less than three years of work experience whereas $30 \%$ had 3 to 6 years of experience. $39.6 \%$ bank branches had $15-20$ employees in one branch, followed by second largest number $30.6 \%$ with 6-10 full time employees.

\subsection{Instrument}

The present study employed the CEAl (Hornsby, et al., 1992) for its investigation in Pakistan context. The CEAl has five dimensions including management support (19-item), rewards reinforcement (06-item), work discretion (10-item), organizational boundaries (07-item) and time availability (06-item). We employed five point Likert scale denominating one as strongly disagree and five as strongly agree.

\section{Analysis and Results}

To analyze the data the PLS path modeling was selected. PLS is a variance-based structural equation modelling technique, that suits structural measurement models; where sample-size is small; and the research is exploratory in nature with the objective of testing and validating models (Hair et al., 2012; Hair et al., 2011; Henseler et al., 2009). Referring to the Wold, (1975) where the model and research settings are exploratory in nature it requires soft-modeling approach. Hence PLS path modelling would be appropriate to use in this context (Barclay et al., 1995).

For ascertaining construct validity of CEAI in Pakistan context, confirmatory factor analysis (CFA) have been used in Smart PLS 2.0 M3 (Ringle et al., 2005). The PLS Algorithm (Geladi \& Kowalski, 1986) was calculated for ascertaining the internal consistency reliability, convergent validity and discriminant validity (Henseler et al., 2009).

Table 1: Confirmatory factor analysis results for CEAI

\begin{tabular}{|c|c|c|c|c|c|c|}
\hline \multirow{2}{*}{ Code } & \multirow{2}{*}{ Indicator } & \multicolumn{5}{|c|}{ Component Loadings } \\
\hline & & MS & OB & RR & TA & WD \\
\hline CEMS10 & Money is often available to get new project ideas off the ground. & 0.6398 & & & & \\
\hline CEMS11 & $\begin{array}{l}\text { Individuals with successful innovative projects receive additional reward and } \\
\text { compensation for their ideas and efforts beyond the standard reward system. }\end{array}$ & 0.7183 & & & & \\
\hline CEMS12 & $\begin{array}{l}\text { There are several options within the organization for individuals to get financial support for } \\
\text { their innovative projects and ideas. }\end{array}$ & 0.772 & & & & \\
\hline CEMS13 & $\begin{array}{l}\text { Individual risk takers are often recognized for their willingness to champion new projects, } \\
\text { whether eventually successful or not. }\end{array}$ & 0.7285 & & & & \\
\hline CEMS14 & People are often encouraged to take calculated risks with new ideas around here. & 0.7074 & & & & \\
\hline CEMS15 & The term "risk taker" is considered a positive attribute for people in my work area. & 0.6218 & & & & \\
\hline CEMS16 & $\begin{array}{l}\text { My bank supports many small and experimental projects realizing that some will } \\
\text { undoubtedly fail. }\end{array}$ & 0.7659 & & & & \\
\hline CEMS17 & A worker with a good idea is often given free time to develop that idea. & 0.7917 & & & & \\
\hline CEMS18 & $\begin{array}{l}\text { There is considerable desire among people in the bank for generating new ideas without } \\
\text { regard to crossing departmental or functional boundaries. }\end{array}$ & 0.7307 & & & & \\
\hline CEMS19 & $\begin{array}{l}\text { People are encouraged to talk to workers in other departments of this bank about ideas } \\
\text { for new projects. }\end{array}$ & 0.6379 & & & & \\
\hline CEMS7 & $\begin{array}{l}\text { The "doers" are allowed to make decisions on projects without going through elaborate } \\
\text { justification and approval procedures. }\end{array}$ & 0.6819 & & & & \\
\hline CEMS8 & $\begin{array}{l}\text { Senior managers encourage innovators to bend rules and rigid procedures in order to } \\
\text { keep promising ideas on track. }\end{array}$ & 0.6628 & & & & \\
\hline CEOB4 & There is little uncertainty in my job. & & 0.7186 & & & \\
\hline CEOB5 & $\begin{array}{l}\text { During the past year, my immediate supervisor discussed my work performance with me } \\
\text { frequently. }\end{array}$ & & 0.835 & & & \\
\hline CERR1 & My supervisor helps me get my work done by removing obstacles. & & & 0.7021 & & \\
\hline CERR2 & The rewards I receive are dependent upon my work on the job. & & & 0.7856 & & \\
\hline CERR3 & My supervisor will increase my job responsibilities if I am performing well in my job. & & & 0.7008 & & \\
\hline CERR4 & My supervisor will give me special recognition if my work performance is especially good. & & & 0.7818 & & \\
\hline CERR5 & My supervisor would tell his boss if my work was outstanding. & & & 0.7043 & & \\
\hline
\end{tabular}




\begin{tabular}{|c|c|c|c|c|c|c|}
\hline CERR6 & There is a lot of challenge in my job. & & & 0.5812 & & \\
\hline CETA2 & I always seem to have plenty of time to get everything done. & & & & 0.7652 & \\
\hline CETA3 & I have just the right amount of time and work load to do everything well. & & & & 0.6933 & \\
\hline CETA6 & My co-workers and I always find time for long-term problem solving. & & & & 0.8103 & \\
\hline CEWD1 & I feel that I am my own boss and do not have to double check all of my decisions. & & & & & 0.6575 \\
\hline CEWD3 & This bank provides the chance to be creative and try my own methods of doing the job. & & & & & 0.6555 \\
\hline CEWD4 & This bank provides freedom to use my own judgment. & & & & & 0.7232 \\
\hline CEWD5 & This bank provides the chance to do something that makes use of my abilities. & & & & & 0.6025 \\
\hline CEWD6 & I have the freedom to decide what I do on my job. & & & & & 0.7597 \\
\hline CEWD7 & It is basically my own responsibility to decide how my job gets done. & & & & & 0.7581 \\
\hline CEWD8 & I almost always get to decide what I do on my job. & & & & & 0.7622 \\
\hline CEWD9 & I have much autonomy on my job and am left on my own to do my own work. & & & & & 0.7406 \\
\hline AVE & & 0.500 & 0.607 & 0.508 & 0.574 & 0.504 \\
\hline CR & & 0.923 & 0.754 & 0.860 & 0.801 & 0.890 \\
\hline
\end{tabular}

Source: Hornsby, et al., (1992)

First, as it depicts in Table 1, that the confirmatory factor analysis yielded five dimensions of CEAI. Secondly, the internal consistency reliability was assessed using composite reliability coefficient. As per the recommendations of Hair, Ringle and Sarstedt, (2011) that the composite reliability coefficient should be at least 0.70 or greater. As indicated in Table 1 the composite reliability coefficient ranges between 0.754 to 0.923 , hence it exceeds 0.70 (Hair, et al., 2011), therefore it demonstrates the adequate internal consistency reliability. Next, we ascertained the convergent validity by evaluating the Average variance Extracted of each of the latent construct (Fornell \& Larcker, 1981). According to Chin, (1998) the AVE of each of the construct should be 0.5 or above. Referring Table 1, the AVE values for each construct demonstrate the higher values than the suggested threshold of 0.5 . Thus all the dimensions of CEAI met the criterion of convergent validity.

Table 2: Construct's discriminant validity

$\begin{array}{lccccc} & 1 & 2 & 3 & 4 & 5 \\ \text { Management Support } & \mathbf{0 . 7 0 7 1 0 7} & & & & \\ \text { Organizational Boundaries } & 0.4384 & \mathbf{0 . 7 7 9 1 0 2} & & & \\ \text { Reward Reinforcement } & 0.3409 & 0.3738 & \mathbf{0 . 7 1 2 7 4 1} & & \\ \text { Time Availability } & 0.5973 & 0.3984 & 0.2696 & \mathbf{0 . 7 5 7 6 2 8} & \\ \text { Work Discretion } & 0.6614 & 0.3332 & 0.3423 & 0.4883 & \mathbf{0 . 7 0 9 9 3}\end{array}$

The correlations of the latent constructs and AVE (values in bold face) are presented in the table above

Lastly, the discriminant validity was ascertained by comparing the correlations among the latent variables with square root of AVE (Fornell \& Larcker, 1981). For each construct the discriminant validity is provided in Table 2 which suggests that all constructs met the criterion of discriminate validity suggesting adequate psychometric properties for the CEAl dimensions (Fornell \& Larcker, 1981).

\section{Discussion and Conclusion}

The present study attempted to validate the CEAl scale (Hornsby, et al., 1992) in the Pakistan banking context, more particularly in the big five banks in Pakistan. Based on the findings of the present study we offer several observations. The confirmatory factor analysis suggests that the CEAI is a multidimensional construct consisting of five dimensions presented in table 1. However, these findings are of no surprise as they are in line with the previous research (Hornsby, Kuratko, \& Zahra, 2002) who theoretically validated the dimensions of CEAl. These results of confirmatory factor analysis, reliability and validity tests submit that these five dimensions of CEAI have proved to be suitable for measuring corporate entrepreneurship in the banking industry in Pakistan other than Canada and USA where the scale was originally developed and tested.

\section{References}

Ag ca, V., Topal, Y., \& Kaya, H. (2012). Linking intrapreneurship activities to multidimensional firm performance in Turkish manufacturing firms: An empirical study. International Entrepreneurship and Management Journal, 8(1), 15-33. 
Al-Swidi, A. K., \& Mahmood, R. (2011). How does organizational culture shape the relationship between entrepreneurial orientation and the organizational performance of banks?. European Journal of Social Sciences, 20(1), 28-46.

Barclay, D., Higgins, C., \& Thompson, R. (1995). The partial least squares (PLS) approach to causal modeling: Personal computer adoption and use as an illustration. Technology studies, 2(2), 285-309.

Benitez-Amado, J., Llorens-Montes, F. J., \& Perez-Arostegui, M. N. (2010). Information technology-enabled intrapreneurship culture and firm performance. Industrial Management \& Data Systems, 110(4), 550-566.

Bierwerth, M., Schwens, C., Isidor, R., \& Kabst, R. (2015). Corporate entrepreneurship and performance: A meta-analysis. Small Business Economics, 1-24.

Brazeal, D.V., 1993. Organizing for internally developed corporate ventures. J. Bus. Venturing 8, 75-90.

Chin, W. W. (1998). The partial least squares approach to structural equation modeling. In G. A. Marcoulides (Ed.), Modern Methods for Business Research (pp. 295-336). Mahwah, New Jersey: Laurence Erlbaum Associates.

Chittipeddi, K. and T.A. Wallett. 1991. "Entrepreneurship and Competitive Strategy for the 1990s," Journal of Small Business Management 29, no. 1: 94-98.

Collin, S. O., \& Smith, E. (2003). Disciplining and enabling action: corporate governance influencing corporate entrepreneurship.

Covin, J. G., \& Slevin, D. P. (1991). A conceptual model of entrepreneurship as firm behavior. Entrepreneurship: Critical perspectives on business and management, 3.

Espinosa, M. D. M. B., \& Suanes, A. M. (2011). Corporate entrepreneurship through joint venture. International Entrepreneurship and Management Journal, 7(3), 413-430.

Floyd, S.W., Woolridge, B., 1990. The strategy process, middle management involvement, and organizational performance. Strategic Manage. J. 11 (3), 231-242.

Floyd, S.W., Woolridge, B., 1992. Middle management involvement in strategy and its association with strategic type: a research note. Strategic Manage. J. 13, 53-168 (special issue).

Floyd, S.W., Woolridge, B., 1994. Dinosaurs or dynamos? Recognizing middle managements' strategic role. Acad. Manage. Exec. 8 (4), 47-58.

Fornell, C., \& Larcker, D. F. (1981). Evaluating structural equation models with unobservable variables and measurement error. Journal of marketing research, 39-50.

Frese, M., Rousseau, D. M., \& Wiklund, J. (2014). The emergence of evidence-based entrepreneurship. Entrepreneurship Theory and Practice, 38(2), 209-216.

García-Morales, V. J., Bolívar-Ramos, M. T., \& Martín-Rojas, R. (2014). Technological variables and absorptive capacity's influence on performance through corporate entrepreneurship. Journal of Business Research, 67(7), 1468-1477.

Geladi, P., \& Kowalski, B. (1986). Partial least-squares regression: A tutorial. Analytica Chimica Acta, 185, 1-17.

Ginsberg, A., Hay, M., 1994. Confronting the challenges of corporate entrepreneurship: guidelines for venture managers. Eur. Manage. J. 12, 82-389.

Hagen, A., Emmanuel, T. and Alshare, K., 2005. Major determinants of entrepreneurship in mid-size companies: Empirical investigation. In: Southwest Decision Sciences Institute, 2005 Conference Proceedings, Dallas, USA, 3-4 March 2005, pp.468-478.

Hair, J. F., Ringle, C. M., \& Sarstedt, M. (2011). PLS-SEM: Indeed a Silver Bullet. Journal of Marketing Theory and Practice, 18(2), 139152.

Hair, J. F., Ringle, C. M., \& Sarstedt, M. (2011). PLS-SEM: Indeed a silver bullet. Journal of Marketing Theory and Practice, 19(2), 139152.

Hair, J. F., Sarstedt, M., Ringle, C. M., \& Mena, J. A. (2012). An assessment of the use of partial least squares structural equation modeling in marketing research. Journal of the Academy of Marketing Science, 40(3), 414-433.

Heavey, C., \& Simsek, Z. (2013). Top management compositional effects on corporate entrepreneurship: The moderating role of perceived technological uncertainty. Journal of Product Innovation Management, 30(5), 837-855.

Henseler, J., Ringle, C. M., \& Sinkovics, R. R. (2009). The Use of Partial Least Squares Path Modeling in International Marketing. In R. R. Sinkovics \& P. N. Ghauri (Eds.), Advances in International Marketing (Vol. 20, pp. 277-320). Bingley: Emerald

Hisrich, R.D., Peters, M.P., 1986. Establishing a new business venture unit within a firm. J. Bus. Venturing 1, $307-322$.

Hornsby, J. S., Kuratko, D. F., \& Zahra, S. A. (2002). Middle managers' perception of the internal environment for corporate entrepreneurship: assessing a measurement scale. Journal of business Venturing, 17(3), 253-273.

Ireland, R. D., Covin, J. G., \& Kuratko, D. F. (2009). Conceptualizing corporate entrepreneurship strategy. Entrepreneurship Theory and Practice, 33(1), 19-46.

Ireland, R. D., Kuratko, D. F., \& Morris, M. H. (2006). A health audit for corporate entrepreneurship: innovation at all levels: part I. Journal of Business Strategy, 27(1), 10-17.

Jones, M. V., Coviello, N. E., \& Tang, Y. K. (2011). International entrepreneurship research (1989-2009): A domain ontology and thematic analysis. Journal of Business Venturing, 26(6), 632-659.

Kanter, R.M., 1985. Supporting innovation and venture development in established companies. J. Bus. Venturing 1, 47-60.

Krejcie, R. V., \& Morgan, D. W. (1970). Determining sample size for research activities. Educational and psychological measurement, 30(3), 607-610.

Kuratko, D. F., Ireland, R. D., Covin, J. G., \& Hornsby, J. S. (2005). A Model of Middle-Level Managers' Entrepreneurial Behavior. Entrepreneurship theory and practice, 29(6), 699-716.

Kuratko, D.F., D.R. Ireland and J.S. Hornsby. 2001. "Improving Firm Performance through Entrepreneurial Actions: Acordia's Corporate 
Entrepreneurship Strategy," Academy of Management Executive 15, no. 4: 60.

Kuratko, D.F., Hornsby, J.S., Naffziger, D.W., Montagno, R.V., 1993. Implementing entrepreneurial thinking in established organizations. Adv. Manage. J. 58 (1), 28-33 (Winter).

Kuratko, D. F., Morris, M. H., \& Covin, J. G. (2011). Corporate innovation and entrepreneurship. SOUTH-WESTERN CENGAGE Learning Australia, United States.

Lisboa, A., Skarmeas, D., \& Lages, C. (2011). Entrepreneurial orientation, exploitative and explorative capabilities, and performance outcomes in export markets: A resource- based approach. Industrial Marketing Management, 40(8), 1274-1284.

Lumpkin, G.T. and G.C. Dess. 2005. "The Role of Entrepreneurial Orientation in Stimulating Corporate Entrepreneurship," Academy of Management Executive 19, no. 1: 147-56.

McGrath, R.G. and I. MacMillan. 2000. The Entrepreneurial Mindset. Cambridge, MA: Harvard Business School Press.

Morris, M.H., Kuratko, D.F., Covin, J.G. (2011). Corporate Entrepreneurship \& Innovation, Entrepreneurial Development within Organisations. Mason:Thomson South-Western.

Naman, J., Slevin, D., 1993. Entrepreneurship and the concept of fit: a model and empirical tests. Strategic Manage. J. 14, 137-153.

Pakistan Banks Association, 2014: Retrieved From: http://www.pakistanbanks.org/

Pearce, J. A., Kramer, T. R., \& Robbins, D. K. (1997). Effects of managers' entrepreneurial behavior on subordinates. Journal of Business Venturing, 12(2), 147-160.

Phan, P. H., Wright, M., Ucbasaran, D., \& Tan, W. L. (2009). Corporate entrepreneurship: Current research and future directions. Journal of Business Venturing, 24(3), 197-205.

Rauch, A., Wiklund, J., Lumpkin, G. T., \& Frese, M. (2009). Entrepreneurial orientation and business performance: An assessment of past research and suggestions for the future. Entrepreneurship Theory and Practice, 33(3), 761-787.

Ringle, C. M., Wende, S., \& Will, S. (2005). SmartPLS 2.0 beta: University of Hamburg, Hamburg. Retrieved from http://www.smartpls. de/forum/index.php.

Sathe, V., 1985. Managing an entrepreneurial dilemma: nurturing entrepreneurship and control in large corporations 636-656. Frontiers of Entrepreneurship Research Babson College, Wesley, Mas.

Simsek, Z., \& Heavey, C. (2011). The mediating role of knowledge-based capital for corporate entrepreneurship effects on performance: A study of small to medium-sized firms. Strategic Entrepreneurial Journal, 5(1), 81-100.

Stevenson, H.H., Jarillo, J.C., 1990. A paradigm of entrepreneurship: entrepreneurial management. Strategic Manage. J. 11, 17-27 (special issue).

Wold, H. (1975). Path models with latent variables: The NIPALS approach (pp. 307-357). Acad. Press.

Zahra, S. A., \& Covin, J. G. (1995). Contextual influences on the corporate entrepreneurship-performance relationship: A longitudinal analysis. Journal of business venturing, 10(1), 43-58.

Zahra, S. A., \& Garvis, D. M. (2000). International corporate entrepreneurship and firm performance: The moderating effect of international environmental hostility. Journal of Business Venturing, 15(5), 469-492.

Zahra, S. A. (2010). Harvesting family firms' organizational social capital: A relational perspective. Journal of Management Studies, 47(2), 345-366.

Zahra, S. A. (2012). Organizational learning and entrepreneurship in family firms: Exploring the moderating effect of ownership and cohesion. Small Business Economics, 38(1), 51-65. 